\title{
Pre-Islamic Arabia and Early Islam
}

\section{Lindstedt, Ilkka Juhani}

Routledge

2018

Lindstedt , I J 2018 , Pre-Islamic Arabia and Early Islam . in H Berg (ed.), Routledge pÿHandbook on Early Islam . Routledge , Abingdon , pp. 159176 . https://doi.org/10.4324/9781315743462-10

http://hdl.handle.net/10138/307521

https://doi.org/10.4324/9781315743462-10

acceptedVersion

Downloaded from Helda, University of Helsinki institutional repository.

This is an electronic reprint of the original article.

This reprint may differ from the original in pagination and typographic detail.

Please cite the original version. 


\section{Early M uslims, Pre-Islamic Arabia, and "Pagans" \\ Ilkka Lindstedt, University of Helsinki ${ }^{1}$}

\section{Introduction and the issue of sources}

Writing about the history or religious map of Arabia in the centuries preceding the birth of Islam is not a simple task. This is especially true for the Hijāz, the region in western Arabian Peninsula which the career of the Prophet M uhammad (ca. 570-632 CE) is connected with. The reason for this is the paucity of evidence and the fact that, in many cases, the sources are much later than the events they depict. However, scholarly studies of recent years have furthered the field very much and the benefit of a holistic approach, which takes into account all source types, has been understood. We are starting to get a picture of Arabia that is full of life, phenomena, religious ideas, and historical events and that is not isolated from the world of late antiquity but is, instead, an intrinsic part of it (Robinson 2010: 7-11). The main powers in and around Arabia were the Byzantine Empire, Sasanian Persia, the kingdom of Axum in Ethiopia, and the kingdom of Himyar in Yemen, all of which wielded influence at times on different parts of Arabia. The main religious currents in Arabia were forms of Christianity (Triningham 1979; Shahîd 1989: 148-229), Judaism (Newby 1988), polytheism (Fahd 1968; Peters 1999) and, to a much lesser degree, Mazdaism (Zoroastrianism). This chapter deals with Arabia of the fourth-sixth centuries especially (for the earlier history of Arabia and Arabians, see, e.g., Bulliet 1975, Bowersock 1983, Eph'al 1984, Shahîd 1984b, Ball 2000, Hoyland 2001, Young 2001, Retsö 2003).

The Arab identity forms a vexing issue that scholars continue to argue about; no consensus has emerged as of yet. In the primary sources, there are only very few instances of someone claiming to be an Arab in the pre-Islamic era: rather, it is a term utilized from the outside. After the Roman conquest of the Province of Arabia in $106 \mathrm{CE}$, it seems that the appellation "Arabs" was used for all inhabitants of the Province regardless of their ethnic identity, which further muddies the waters (Hoyland 2009: 392-393). As argued by Peter Webb in another chapter of this book, ${ }^{2}$ the real ethnogenesis of the Arabs should probably be placed in the Islamic period (cf. Hoyland 2001: 229-247; Hoyland 2007; M acdonald 2009a and 2009b). Averil Cameron (2012: 179) notes: “The difficulty remains of matching modern notions of 'Arab', 'Syrian', 'Semitic' and other such terms, which are still entangled in a mesh of confusion and even prejudice, with the actual situation in our period." Because of this, this chapter refers to the inhabitants of Arabia as

\footnotetext{
${ }^{1}$ I have greatly benefitted from discussions with Nathaniel Miller about pre-Islamic Arabia. I am grateful to him as well as to Prof. Jaakko Hämeen-Anttila who read and commented on an earlier draft of this chapter.

${ }^{2}$ To the editor: Peter is writing a chapter in this book, correct? - IL
} 
"Arabians," sometimes with the qualifying attributes "North" or "South." The word "Arab(s)" is only used when it appears in the sources.

Before proceeding any further, we have to discuss the issue of sources. The sources for pre-Islamic Arabia fall into three categories:

1) Archaeological remains: Excavations in Arabia have not been as numerous as one would hope but important archaeological work and field surveys have been carried out around the Peninsula and their results published (see, e.g., Potts 1990-1991; Hoyland 2001: 167-197; Finster 2009; Genequand 2015). However, there have been no archaeological excavations in or in the immediate vicinity of M ecca and Medina.

2) Documentary sources, in particular epigraphy: There are tens of thousands published inscriptions written in Ancient North Arabian (ANA) and Ancient South Arabian (ASA) scripts and languages (M acdonald 2000). Nabataean Aramaic inscriptions are also very significant, especially the ones that are written in the late (transitional) variety of the script that was still used in the fifth century CE and from which the Arabic script is derived (Nehmé 2010). Old Arabic inscriptions, on the other hand, are fewer in number (M acdonald 2008; Al-Jallad 2014). ANA and ASA inscriptions are very interesting because of their references to pre-Islamic deities but the dating of the ANA inscriptions in particular is problematic. The received opinion is that the writing of ANA inscriptions die out by the fourth century $C E$, but there is no definitive evidence to that effect (on the question of dating, see Al-Jallad, forthcoming). ${ }^{3}$ In any case, almost all of the ANA inscriptions are undated by their writers and there are currently no tools for the researcher to endeavor to put forth dates. Thus the usability of this corpus for understanding the nascent Islam is diminished until further proof of their dating emerges. The ASA inscriptions are often dated or datable and continued to be written at least until the sixth century CE (Nebes \& Stein 2008: 145), but they hail from Yemen, which is culturally different from the northern parts of Arabia where Islam began (Robin 2001). ASA survives not only as rock inscriptions but also on wooden sticks written in a minuscule script (Ryckmans \& M üller \& Abdallah 1994). Many more, perhaps tens of thousands, Arabian inscriptions still remain undiscovered and unpublished.

3) Literary sources: The Arabic and non-Arabic (especially Greek and Syriac) literary corpus is one that is most often used by historians to trace the events and religious phenomena of pre-Islamic Arabia. Islamicists have in the past relied almost solely on the Islamic-era Arabic literary evidence when they explore the pre-Islamic background of the Hijāz and the Prophet M uhammad (e.g., Lecker 2005). It is, however, often tendentious and centuries later than the events: the first specimens of Arabic

\footnotetext{
${ }^{3}$ There are a couple of indications that some ANA inscriptions could be contemporaneous with Islam. See, e.g., the Safaitic inscription CIS 4448 in Al-Jallad 2015: 242, which is dated according to s'nt hrb h-mdy 'I rm b- bșr[y], "the year the Persians waged war against the people of Rome at Bostra." The inscription could refer to the Sasanian-Byzantine wars of the early seventh century CE.
} 
historiographical and other literary texts hail from around the year $800 \mathrm{CE}$ (on the development of Arabic historiography, see Donner 1998). M aterial remains show that many pieces of information contained in Arabic literary evidence are inaccurate; on the other hand, they ascertain other details. Arabic texts such as Ibn al-Kalbī's Kitāb al-Așnām clearly have some authentic material about the religious beliefs of pre-Islamic Arabia but separating the wheat from the chaff is difficult. To quote Robert Hoyland (2009: 389): "[It] must be borne in mind that the Arabic reports are not plain historical narratives, but rather of an epic and legendary nature, full of seductions, ambushes, eloquent speeches and heroic battles."

Nevertheless, the Islamic-era Arabic texts can be studied from another point of view: namely, the narrative and Weltanschauung that they offer in which the pre-Islamic jāhiliyya, "Age of Ignorance," is seen as a complete opposite to the time of Islam (Drory 1996; Rippin 2012: 7-17). When studying "how it really was," we must, however, give precedence to the material remains where they exist, and use literary sources with a critical eye. M ore research is needed on the question of transmission of pre-Islamic information to the later Arabic literary sources (for some notes, see Hoyland 2009: 390-391). Muslim authors who write on pre-Islamic Arabia sometimes refer to written sources that they had at their disposal. For example, al-Hamdānī (Iklil: I, 118-119, 131), an expert on South Arabian matters, refers to zabūrs and sijills, some kind of written books and records that he used, but the existence or character of these is unclear. Furthermore, the Middle Persian Khwadāy-nāmag, "Book of Kings" literature, different specimens of which were translated into Arabic (Hämeen-Anttila 2013), might have included some information on North and South Arabia. However, it might be the case that the reports on Arabia were added during the translation process and thus postdate Islam.

In connection with the Arabic sources one must also mention the originally oral Arabic poetry that is attributed to the pre-Islamic era even if it was collected in the first centuries of Islam. Some earlier scholars (M argoliouth 1925; Husayn 1926) dismissed the whole of this corpus of poetry as a forgery but a case can be made that the formal features of these poems (meter, rhyme) guaranteed that they were transmitted in a way that was more or less faithful to their original form(s) (see also Zwettler 1978). Most modern scholars are of the opinion that, if genuine, the pre-Islamic poetry stems from the fifth-sixth century $C E$, at the earliest. Study that compares this corpus to the epigraphic record, for example, is still in its infancy.

\section{Languages of pre-Islamic Arabia}

To show how at loss the Islamic-era Arabic literary evidence can sometimes be, one needs only to consider the linguistic situation of pre-Islamic Arabia (on which see M acdonald 2000 and Al-Jallad 2015: 1-25). The M uslim authors did not have an understanding of the variety of languages in the pre-Islamic era, claiming that most of the inhabitants of Arabia were Arabic-speaking (Rabin 1951), whereas in historical reality Arabia was home to speakers and writers of forms of North Arabian (including but not restricted to Arabic), South Arabian, Aramaic (Nabataean, Syriac) and, to lesser extent, Hebrew, Ge'ez, Persian, Greek, and Latin. 
In the Islamic tradition, not only Arabians but also major characters of the monotheist tradition such as Ismail speak Arabic (al-M as'ūdī, M urūj: II, 162). Furthermore, later Arabic writers had little grasp that the South Arabians did not see themselves as and could not be called Arabs in the pre-Islamic era. The Muslim authors see Yemen as the original home of the Arabs and Arabic language - an idea of which we do not have much evidence and that is most likely incorrect.

To this is connected another myth, namely that the Arab tribes are divided to two section: al- arab al- 'āriba, "True Arabic-speaking Arabs," and al-'arab al-musta 'riba, "Arabized Arabs." The 'arab al-'āriba are deemed to be the Southern tribes and the arab al-musta 'riba Northern. But this is incorrect insofar that the Arabic language actually spread from the north to the south in the course of late antiquity, and not the other way around. The Islamic tradition pushes the importance of Yemen even further, for example claiming that the eponym of the Greeks, Yūnān, came from Yemen (al-Mas'ūdī, M urūj: II, 5-6). All of this probably reflects Islamic-era, post-conquest tendency of Yemenite Muslims to emphasize their significance but this needs further research (for some notes see Bashear 1989).

In the Muslim sources, the development and rise of the Arabic script is said to have happened in the Ḥijāz, al-Anbār, or al-Ḥîra (e.g., al-Hamdānī, Iklîl: I, 77-79). The suggestion of al-Ḥīra is interesting, since it was the capital of the Lakhmids (see below) and, indeed, the first text that is written completely in Arabic is the Namara inscription dated to $328 \mathrm{CE}$; it is a funerary text for Mar' al-Qays ibn 'Amr, who is usually identified with a Lakhmid king of that name (Bellamy 1985). The script is a late variant of Nabataean, of which the Arabic script developed during the following centuries (Gruendler 1993). However, the Namara inscription is the only testimony for the Lakhmids' ostensible written use of Arabic.

As for the Hijāz, there is actually more evidence that the Arabic script evolved there. Based on epigraphy, the rise of the Arabic script seems to be more directly related with the longevity of Nabataean Aramaic that was, according to new finds (Nehmé 2010), used in the western parts of the peninsula until the fifth century. The script of these inscriptions is Nabataean and the language is often a mixture of Aramaic and Arabic. In 2014, Frédéric Imbert and a French-Saudi team found a new Nabataean AramaicArabic inscription dated 469-470 CE as south as Najrān, which sparked scholarly and media interest. ${ }^{4}$ The Old Arabic inscriptions of the sixth century (Zebed, Jabal Usays, Harran; see M acdonald 2008) seem to be continuation of this epigraphic habit of late Nabataean inscriptions, even if they have been found to the north of the Hijāz, in Syria. Writing on perishable material, if it existed, has not been preserved.

\footnotetext{
${ }^{4}$ See http:// www.diplomatie.gouv.fr/fr/dossiers-pays/arabie-saoudite/la-france-et-l-arabie-saoudite/ evenements-

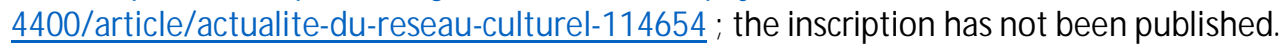




\section{Tribal groups}

There is a rather widespread misconception among the general audience that all or most of the inhabitants of Arabia, and especially the Hijāz, were nomadic (often called, anachronistically, Bedouin) around the lifetime of the Prophet M uhammad, that is, the sixth and seventh centuries CE (on nomadism in Arabia, see, e.g., Bulliet 1980; Donner 1981: 16-20; Hoyland 2001: 89-102; W. Lancaster \& F. Lancaster 2004). But this is incorrect. As Fred Donner (1981: 11) reminds us about the inhabitants of Arabia: "it is unlikely that nomadic peoples have ever formed more than a small fraction of its population... M ost Arabians, then, are, and have been, settled people." It has to be remembered that according to the traditional narrative, Muhammad himself was a town-dweller, not a nomad of the desert.

Inhabitants of Arabia were divided along tribal lines that could be, if need be, flexible and negotiable. There is sizeable secondary literature on pre-Islamic Arabian tribal groups (e.g., Kister 1965 on Tamīm; Donner 1980 on Bakr ibn Wā'il; Shahîd 1984a: 366- 483 on Tanūkh; Landau-Tasseron 1985 on Asad; Lecker 1989 on Sulaym; Lecker 1994 on Kinda; Rihan 2014 on 'Āmila). It can be assumed that the Arabic literary evidence did transmit some historically valid knowledge of the tribes on the eve of Islam. In another section below, the Banū Ghassān, Șāliḥ, and Lakhm will be discussed; of these, the Arabic literature has valuable material. But when it comes to earlier times, it probably does not have much authentic information, expect perhaps genealogies, which have proven to be very accurate.

The following two are extreme examples of the unreliability of Arabic literature: the extinct tribes, Thamūd and 'Ād. They are treated here to remind the students of pre-Islamic Arabia that especially the sacred history is often of doubtful reliability. A critical examination of the Islamic sources (the Qur'ān and the later tradition) shows that M uslims did not have any information about the historical Thamūd (on which see Macdonald 1995). The Thamūd narrative in the Islamic source is, quite simply, a myth (Stetkevych 1996). It tells the story of the Thamūd that live in al-Hijr (ancient Egra/Hgr', modern Madā'in Șāliḥ), a city carved out of rock (Q. 11:61-68; 15:80-84; 41:13-17; al-Ṭabarī, Ta'rikh: I, 244-252). A prophet, called simply șāliḥ, "Pious," emerges from among them, but the Thamūd disbelieve and God's punishment wipes them all out. But in historical reality, al-Hijr was a Nabataean city (see e.g. Nehmé 2005). Writing of Nabataean Aramaic in al-Hijr survived the fall of the Nabataean state in 106 well into the fourth century CE. There is no evidence whatsoever that Thamūd lived there before or after the Nabataeans. It should be reminded, at this junction, that the varieties of Ancient North Arabian inscriptions called "Thamudic" do not have anything at all to do with the tribe Thamūd; "Thamudic" is merely a modern and unfortunate misnomer. The Islamic sources are correct, though, in that the Thamūd seems to have been an extinct tribe before Islam. The last mention of them is in the fifth-century CE Byzantine military document Notitia Dignitatum (Shahîd 2000: 436a). Al-Hijr, a city that was probably more or less abandoned by the lifetime of 
M uhammad, became connected in the minds of the people with a lost tribe, the Thamūd. But for the study of the historical Thamūd, the Islamic sources are of little or no value.

Another extinct tribe, 'Ād, is mentioned in connection with the Thamūd in the Qur'ān (e.g, 7:73-4). In one passage (89:6-7), the Qur'ān states: "Have you not seen how your Lord dealt with the 'Ād of Iram of pillars?" (iram dhāt al- imād). The Arabic exegetical tradition speculates extensively what this "Iram of pillars" might have been. Usually it is stated that it was either a city, identified with Damascus, the ancient Aram, or a (non-attested) place of that name in Yemen, or a tribe somehow related with the 'Ād. But a case can be made that the Qur'ānic Iram is nothing else but the ancient Nabataean town of Iram, nowadays known as Wādī Ram, in Jordan (Healey 2001: 56). Iram ('rm) as a toponym is securely attested in the inscriptions from the area (Savignac 1933). For example, one Bar 'Aliyyū, writing on Jabal Ram, says that he wrote the inscription with his own hand in 'rm (Hoyland 2010a: 39). Indeed, Jabal Ram is still called Iram in the Islamic times (Yãqūt, M u jam: I, 154-155). But the epigraphic evidence can be pushed even further, since a Hismaic inscription found on a stone from the temple of Lāt in Iram/Wādī Ram is written "by Ġt son of 'Slh son of Ikm - and he built the temple of Lāt (w-bny bt lt) - of the tribe 'd" (Farès-Drappeau 1996: 276-277). ${ }^{5}$ The Hismaic ' $d$ can be interpreted as the Arabic 'A $d$ (Hismaic does not write vowels, even long ones), which would then place the 'Ād in the ancient Iram. The pillars (al- 'imād) mentioned in the Qur'ān could then be understood as the buildings or, perhaps more plausibly, as the rock formations of Iram.

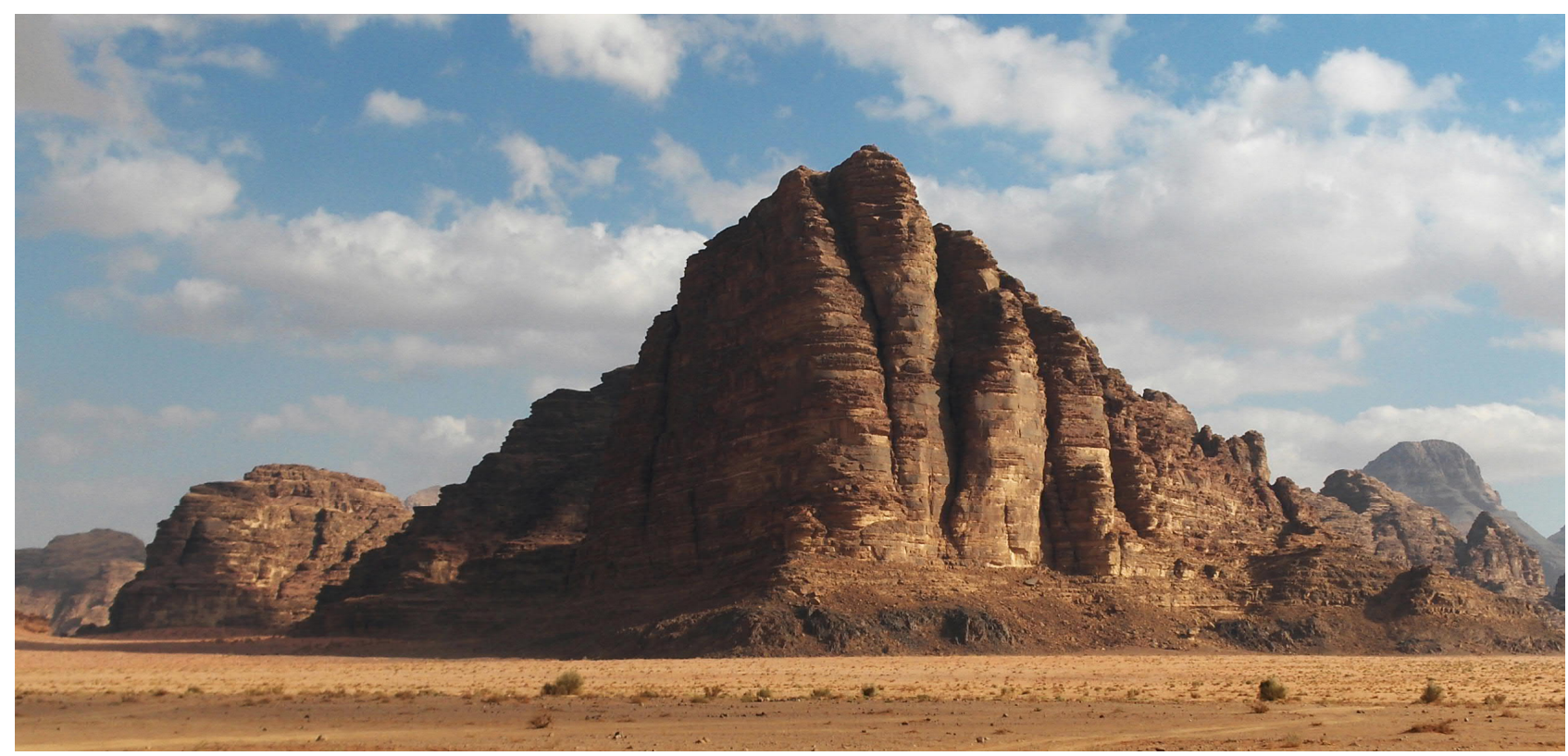

Fig. 1: A rock formation from Wādī Ram named, in modern times, as the Seven Pillars of Wisdom.

$$
\text { Photograph by "Tomobe03," }
$$

https://commons.wikimedia.org/wiki/File:Seven_Pillars_2008_e5.jpg\#/media/File:Seven_Pillars_2008_e5.jp

\footnotetext{
${ }^{5}$ I thank Yusuf Gürsey for this reference.
} 


\section{The Hijāz and polytheism}

In the Islamic-era Arabic narratives, the pre-Islamic history of Mecca is linked with the sacred history and, sometimes, the history of Persian Empire. For example Sāsān, the eponym of the Sasanids, is depicted as going to Ka'ba for a pilgrimage (al-M as'ūdī, M urūj: I, 283). The building of Ka'ba is credited to Abraham, as is well known. But this is of course nothing but pious fiction. This section discusses political events and religious beliefs in the Ḥijāz before Muhammad based on documentary evidence. Epigraphy receives much space here, because many of the inscriptions are rather new finds and somewhat unknown to students of pre- and early Islamic history.

Mecca, the town were Muhammad is said to have been born, was not suited for agriculture (Donner 1981: 15): it seems to have been an insignificant town in pre-Islamic times and it is not referred to by any source before the coming of Islam (identifying Ptolemy's M acoraba with M ecca is not credible). The first source to mention it is the Qur'ān (48:84; furthermore, in 3:96 a place called Bakka, often identified with M ecca, appears). It needs to be stressed that the trans-Arabian trade routes did not pass through it (Crone 1987; cf. Bukharin 2009). M ecca seems to have been a minor town with a temple, the Ka'ba, where some Arabians made the pilgrimage to. Even though we do not have pre-Islamic references to M ecca or Ka'ba, we do have ample evidence of sacred enclaves (in Arabic, haram, mahram, or himā), where violence was prohibited, in the Peninsula. These are attested in ASA and Nabataean Aramaic inscriptions as well as literary evidence (Nehmé 1998; Hoyland 2001: 157-162). The sanctuary usually employed a priest of some kind and pilgrimage to the site could be done. From Yemen, we have epigraphic record that describes annual pilgrimages to different sanctuaries; during the pilgrimage and festival time, shedding blood and sexual relations were often forbidden (Hoyland 2001: 161). In the Arabic literature, we also have references to other ka 'bas (cubic religious buildings) of the Peninsula (Finster 2009: 75-76, 85-86).

More significant than M ecca in antiquity was the other town which M uhammad's life is linked with, Medina, known before Islam as Yathrib. Yathrib is widely attested in both pre-Islamic epigraphy and literature and was a stop along the trade route. Whereas M ecca seems to have been polytheist in the main, monotheism (particularly Judaism) was rather strongly represented in Yathrib (Lecker 1995). Jews are attested in epigraphy also elsewhere in the Hijāz and Northern Arabia (Hoyland 2011). However, we currently have very little tangible evidence for Christians in or around M ecca and M edina (M unt 2015: 252).

The religious environment of the Hijāz around the time of M uhammad seems to be one where older polytheism was mixed with newer strands of monotheism (Christianity and Judaism): “The Qur’ān crystallized in an environment of monotheistic debate, not in a pagan environment" (Donner 2011: 29). In fact, some scholars (Hawting 1999, Crone 2010), have gone as far as to claim that the Qur'ānic mushrikūn, usually translated as "polytheists," were actually some sort of monotheists (or quasi-monotheists). This is analogous to what the late antique scholars of the Greco-Roman world have noticed, namely, that there 
was a general tendency toward "pagan monotheism" (Athanassiadi \& Frede 1999). The Qur'ān (29:65), for example, says that "When they go on board a ship, they call on God (allāh), in sincere devotion to Him alone, but once He has delivered them safely back to land, they ascribe partners." This could indicate that even the polytheists viewed Allāh as some sort of High God (Watt 1971). But there is no evidence outside the Qur'ān for this (Bowersock 2013: 120-133). It must be noted that the Qur'ān ascribes often in a polemic vein opinions and beliefs to the enemies of the Believers that they probably did not manifest. Discussing the characterization of Christianity in the Qur'ān, Sidney Griffith (2011: 311) remarks: "the Qur'ān does not simply report or repeat what Christians say; it reproves what they say, corrects it, or caricatures it." This serves as "a polemically inspired caricature, the purpose of which is to highlight in Islamic terms the absurdity, and therefore the wrongness, of the Christian belief" (idem.). In attributing the mushrikūn some monotheist tendencies, the Qur'ān is probably doing the same: it claims that even the polytheists acknowledge that Allāh is the only and real God when their lives are in peril but when the danger is over they resort to their false gods again. In fact, it is rather widely attested that polytheism was still practiced in parts of Arabia, and we do not seem to have any reason to doubt that the Ka'ba of M ecca was a place where a pagan god, perhaps Hubal and possibly represented by the black stone, was worshipped (e.g., alAzraqī, Akhbār: 31; the deity hblw is attested in a Nabataean inscription from Madā'in Șālih, Healey 1993: 154).

The effect of the M azdaean (Zoroastrian) religion on the region before and during the life of M uhammad was less significant than that of Christianity and Judaism, but scholars have suggested some influences. However, it is hard to say whether these influences are real or imagined: the evidence is slight. The Sasanian ruler Kavād I, who reigned in the late fifth and early sixth centuries, is said to have imposed M azdaism upon the Arabians in Najd and the Hijāz (al-M as'ūdī, M urūj: I, 75; Daryaee 2009: 27) but whether this is a reliable report is hard to judge. In the Qur'ān (2:102), angels called Hārūt and Mārūt appear; the names seem to be influenced by the M azdaean divine concepts Haurvatat (M iddle Persian hordad, lit. "perfection") and Ameretat (M iddle Persian amurdad, lit. "immortality") that were among the Amesha Spenta (Rose 2011: 171).

We have ample epigraphic evidence of Arabian polytheistic beliefs and rites in the ANA (especially Safaitic), ASA and Nabataean inscriptions. The problem is that these are (often centuries) earlier than M uhammad and the Qur'ān, making it unclear whether this corpus is always to useful study the context of early Islam. What is more, the epigraphic evidence stems mostly from the south and north of the Hijāz. However, it can be argued that the epigraphic record is nonetheless more valuable than the Islamic-era Arabic literary evidence, which is centuries later than M uhammad and composed after what was seen as a profound change in the world order: the coming of new religion, Islam, and the conquest of almost all of the known world by its adherents. 
The Safaitic inscriptions are especially interesting because they are voluminous (over 30.000 are known so far), rather well-understood, and paint a vibrant picture of the religious beliefs of their writers, the inhabitants of the Syro-J ordanian harra, the basalt stone desert. The inscriptions attest religious rituals, such as sacrificing animals $(\underline{d} b h)^{6}$ or dedicating (qșy) an animal in a rock drawing to a deity; the writers also mention going on a pilgrimage (hg) (Al-Jallad 2015: 217). Quite a few deities feature, many of which are identifiable with the ones mentioned in the Qur'ān or later Arabic literature as being among the deities that the polytheists worshipped: for example, 'Ih, 'It, $d s^{2} r(y) / d s^{2} r(y)$, and rdw/rdy (Al-Jallad 2015: 210), corresponding to Allāh, Allāt, Dhū al-Sharā, and Ruḍa in Arabic. The inscriptions reveal that the writers sought refuge in the deities when the times were tough:

By S'd son of S'w't son of Lm' and may Rḍw help him through divine favor, as there is danger here, and may he bless him (AWS218 in Al-Jallad 2015: 226). ${ }^{7}$

By $\left\{n^{\prime} m\right\}$ and $O\left\{G d^{\prime} w d \underline{d}\right\}, O$ Merciful One ( $h \mathrm{rhm}$ ) and $O$ One who causes death (h ymyt), and O Rḍ, may the people be established [in this place] (C 4351 in Al-Jallad 2015: 241).

The deities (or attributes) rhm and ymyt mentioned in C 4351 are especially interesting and should be compared with the divine attributes mentioned in the Qur'ān.

By M lk son of 'hwd of the lineage of ' $m n$ and he halted on account of a monitor lizard the year M $\mathrm{k}$ announced (declared war?) for Rome; and he mourned for S'yd, who was murdered, so, 0 Lt, may there be vengeance against his murderer; and he mourned for his paternal uncle's captured son, whom Țayyi' have captured (CSNS 1004 in Al-Jallad 2015: 245).

By Nžr son of Hffẓ son of S'wd and, O King of the sky (h mlk h-s'my), let there be water (KRS 1944 in AlJallad 2015: 262).

\footnotetext{
${ }^{6}$ Animal sacrifices are attested in jāhiliyya poetry and archaeological record, as well. One of the forms of animal sacrifice was that a camel was killed on the death of its owner (Stetkevych 1993: 40; Hoyland 2001: 163-166, 175). ${ }^{7}$ The readings of the Safaitic inscriptions are from Al-Jallad 2015. The translations have been modified if deemed necessary.
} 


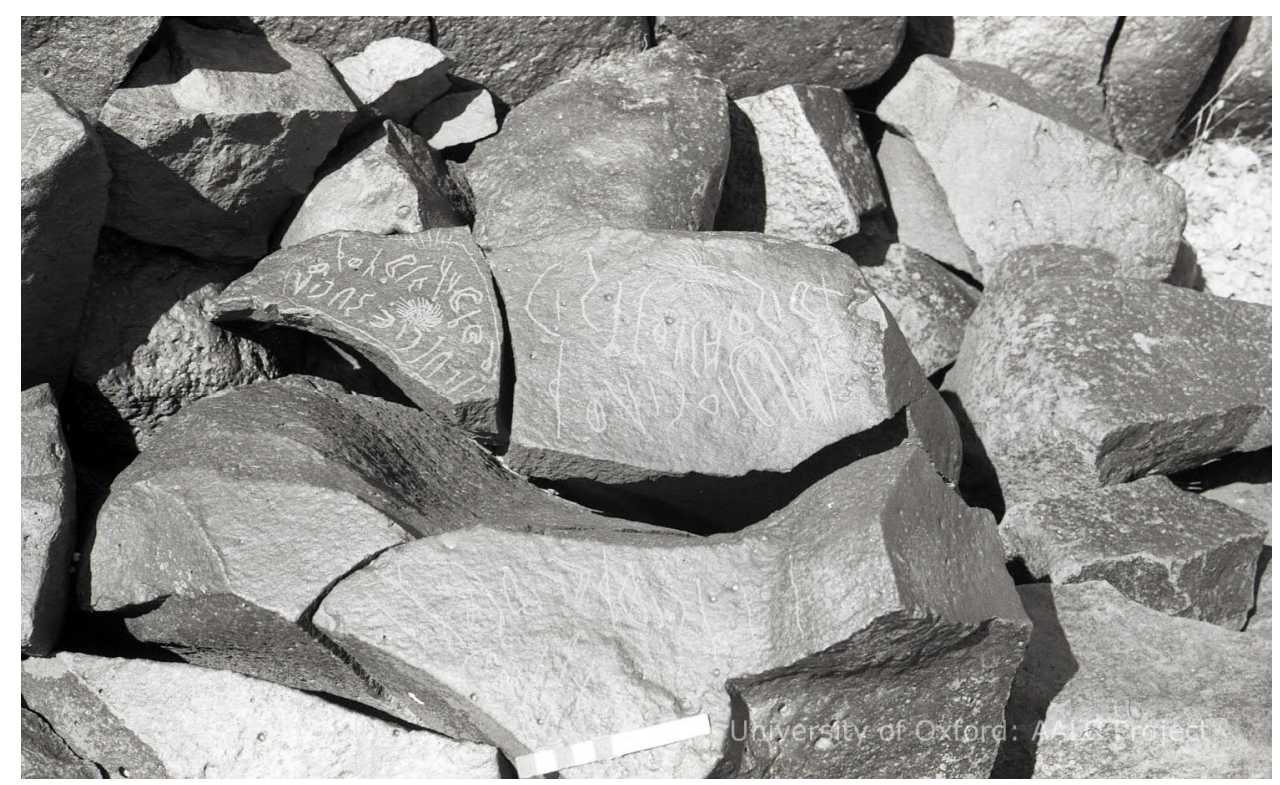

Fig. 2: Safaitic inscriptions, among them KRS 1944 (left), quoted above. In the middle of the inscription, there seems to be a drawing of the sun disc which is very fitting since the invocation is addressed to "King of the sky."

Other Safaitic inscriptions speak of more worldly matters, such as:

By Bt and he copulated with Grmh, as he had celebrated the sending of the bride and had been pleased (C 285 in Al-Jallad 2015: 229).

By Whblh son of 'hrb son of Ykn of the lineage of Kkb and he rejoiced at Brkt because there was fresh herbage, and returned from a place of water the year the lineage of ' $w \underline{d}$ pastured the livestock of the lineage of 'bd; and he served with his father in a cavalry unit (C 320 in Al-Jallad 2015: 229).

The inscriptions show that the inhabitants of the harra were of habit of naming years according to significant events, especially wars. This is analogous to what we read in Arabic sources, where years such as "the year of the elephant" ( 'ām al-fil) appear. To give a couple of examples from the Safaitic corpus:

By 'n'm son of Qhss² and he raided in the year of the war of Nabataea (C 3690 in Al-Jallad 2015: 240).

By Kḥs'mn son of Gn'l son of S'r son of Gn'l of the lineage of Kn and adversity was widespread in the year of Caesar and the Persians so, 0 Lt and Gdḍf, may he be secure; and may he who would efface this writing go blind (HAUI 72 in Al-Jallad 2015: 248). 
By Z'n son of Grm'l son of $Z^{\prime} n$ son of Bnt son of $Z$ 'n son of $\underline{H}$ s't of the lineage of $K n$ and he found the writing of Grm'l, for those who remain despair; and he feared the Romans in the year of the Jews so, 0 Lt, ... protection against misfortune (HAUI 125 in Al-Jallad 2015: 249).

As is already clear from the above examples, the writers of the Safaitic inscriptions often mention the powers in the region: Nabataeans, Romans, and Persians. One could adduce two more inscriptions to this effect, in the latter of which erecting (nșb) a sacred stone for a deity is mentioned. Sacred stones, representing deities, are widely attested in archaeological, epigraphic and literary evidence (Hoyland 2001: 183-187).

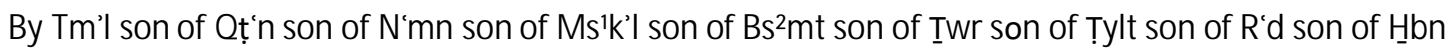
son of Qn'l the HWl-ite and he fled from Rome/Romans (LP 87 in Al-Jallad 2015: 265).

By N'mn son of Hbyt son of Nșr son of N'mn son of Nșr son of \{Grm'l\} son of Kn son of N'mn son of W'I son of Rbn son of $\mathrm{S}^{2} r$ son of Kn son of Țhrt son of Hys'r son of B' ${ }^{2}$ son of Df and he erected (nșb) [a sacred stone of] ' $t$ ' the year Caesar sent reinforcements to the province and restored order to the province and the lineage of 's' $\mathrm{hm}$ was defeated, for the lineage of M Ik and ' $\mathrm{m}$ the 'bs'ite and ' $\mathrm{s}^{1}$ of the lineage of Frt and he/ those of the lineage of Yẓr had [all] made war upon them (M ISSD 1 in Al-Jallad 2015: 273).

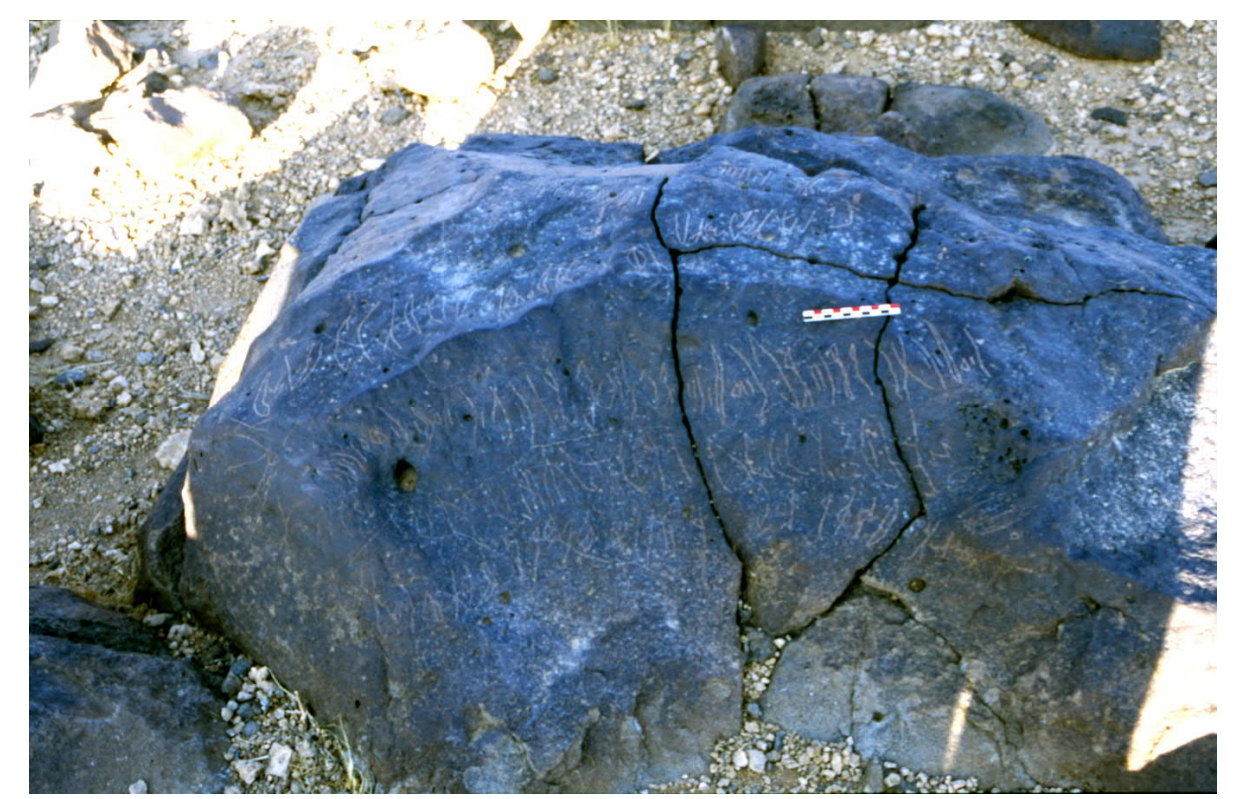

Fig. 3: An unusually long Safaitic inscription MISSD 1, photograph courtesy of M ichael M acdonald.

Polytheism features also in the late Nabataean Aramaic inscriptions, meaning Aramaic inscriptions written in transitional Nabataean script and often with heavy influences of Arabic (what follows is based on 
Nehmé 2013: 69-73). While we can often only guess the dates of the Safaitic corpus, these inscriptions are rather securely dated to the first-fifth centuries CE on the basis of explicitly mentioned dates and paleography. What is more, the late Nabataean inscriptions all derive from the Hijāz and not outside of it. Four deities, all recognizable from the Qur'ān and the later Arabic tradition, occur in them: the Nabataean main god dwšr' (Arabic Dhū al-Sharā), 'l'z' (al-'Uzzā), 'It (Allāt) and mntw/mnwt/mnwtw (Manāt). In addition to these, two inscribers ask to be remembered "in front of all the gods" (mn qdm 'lhy' klhm). Highly interesting is the sole inscriptions that mentions Allat, since it states d' 'It dy bnh 'nmw, "this is [a stone representing] Allāt that 'Nmw built" (on Allāt, see Krone 1992). The inscribers mentioning the different deities ask to be remembered in front of one ( $\mathrm{dkyr} P N \mathrm{mn}$ qdm DN) or that the deity listens to or hears (the prayer of) PN (šm t DN I- PN).

Polytheistic rites among North Arabians are also recounted in the pre-Islamic literary evidence, such as the Latin Itinerarium written by the anonymous "Piacenza Pilgrim" probably in the 550s. The author mentions a sacred stone on M ount Sinai:

And on this mountain, on a part of the mountain, the Saracens have set up their own idol, made of marble white as snow. Here also their priest resides, dressed in a dalmatic and a linen cloak. When the time of their festival arrives with the new moon, before the moon has risen on the day of their feast, the marble begins to change colour; as soon as the moon appears, when they begin to worship, the marble turns black as pitch. When the time of the festival is over, it returns to its original colour. We were totally amazed by this (Piacenza Pilgrim, Travelogue: 38, transl. in Caner 2010: 258).

The point of this section was to show that polytheism of pre-Islamic North Arabia is widely attested in epigraphic record and literature and there does not seem to by much reason to suggest, as Patricia Crone $(2010,2012)$ has done, that the mushrikūn mentioned in the Qur'ān were monotheist or believers in the same god, Allāh, as the Prophet, even though in some instances the Qur'ān uses the word for people who were not deemed monotheist enough, such as Christians or Jews (e.g., Q. 9:30-31). What is, in contrast, true is that according to the pre-Islamic documentary record Allāh is very rarely attested, which casts in doubt the "High God" theory (at least in so far it was Allāh). Polytheist pantheon and rites in South Arabia differed from those of North Arabia and will be discussed in the next section.

\section{Yemen}

Yemen is the only part of the Arabia Peninsula able to sustain dry-farming (Donner 1981: 11-12). Yemen was, before Islam, culturally very different from the more northern parts of the peninsula: the Yemenites spoke and wrote forms of South Arabian whereas the inhabitants of the north spoke forms of North Arabian. The two language bundles are part of the Semitic family, but they are not so closely related: 
alongside the Ethiopian languages South Arabian forms the South Semitic subdivision, while Ancient North Arabian and Old Arabic are part of Central Semitic (M acdonald 2000). The Yemenites did not view themselves as Arabs before the coming of Islam and neither should the modern scholarship call them that. (To be sure, it was suggested in the introduction to this chapter that the term "Arab" could also be inapplicable to North Arabians in pre-Islamic times.) What is more, the Yemenites formed political units and states much earlier than they appear in the North. Their income was secured because Yemen produced frankincense and myrrh, valuable products in antiquity that were transported to, for instance, Rome (for the spice and incense trade in and from Arabia, see, e.g., Hourani 1979: 3-50; Crone 1987; Young 2001). The trans-Arabian trade is ultimately tied to the domestication and exploitation of the camel as a pack animal (Bulliet 1975).

The Yemenite kingdom of Himyar is characterized by its close, and sometimes hostile, relationship with the kingdom of Axum (Ethiopia) that had converted to Christianity by the 340s (Bowersock 2013: 67). Christianity had also spread to some parts of Yemen, especially Najrān, but, interestingly and because of reasons that we do not have clear grasp of, towards the end of the fourth century, Yemen, or at least its ruling class, adopted Judaism with some peculiar characteristics (Robin 2003; Gajda 2010). Before this, the Yemenites were mainly polytheist, worshipping, among others, 'Athtar, the sun goddess Shams and the moon god Almaqah (Jamme 1947; Hoyland 2001: 140-141). (The importance of astral deities in North Arabia is a debated question, see Macdonald 2012; interestingly, however, Q. 53:49 calls God "the Lord of Sirius".) The South Arabian deity Wadd is mentioned in the Qur'ān (71:23) along with other, unidentifiable deities, so it seems reasonable to suppose that traditional South Arabian polytheism was practiced until the life of Muhammad, even though it vanishes completely from the South Arabian inscriptions that are dated between 380 and 560. The new monotheist God is called rhmnn in Ancient South Arabian and often described as "Lord of Heaven and Earth" (Nebes 2009). The Qur'ānic name al-Rahmān is probably related to that. One interesting inscription ends, after mentioning rhmnn, with the phrase rb hd b-mhmd, which is translated as "by the Lord of the Jews, by the Highly Praised" (Ja 1028 in CSAI), even if the similarity to the Prophet Muhammad's name is probably purely coincidental.

In 518 or thereabouts, the Ethiopian Negus (king) raided Yemen which led to a short Christian occupation (Bowersock 2013: 87-93). But the staunchly Jewish Ḥimyarite king Yūsuf, known in Arabic tradition as Dhū Nuwās, fought against the Christianizing trend and, in 523, went so far as to massacre Christians in Najrān and other places (see, e.g., al-M as'ūdī, M urūj: I, 74-75; Brock \& Harvey 1987: 100-121; Beaucamp \& Briquel-Chatonnet \& Robin 1999-2000 and 2010). This led to a new Ethiopian attack to Yemen, possibly at the instigation of the Byzantines, in 525 (Bowersock 2013: 96-97). The Ethiopian and Christian presence in Yemen was strengthened and the Himyarite dynasty was supplanted. This led to a situation were also other foreign powers tried to yield influence in Southern Arabia. During Khosrow I ( $r$. 
531-579), Sasanian Persia was able to conquer areas in Eastern Arabia, reaching regions in Yemen too (Daryaee 2009: 31).

In the 540s-550s, Yemen was ruled by a king of Ethiopian origins called Abraha. He launched many campaigns to parts of Arabia, celebrating his deeds in inscriptions (Bowersock 2013: 111-118). One expedition, probably the one dated 552, was remembered later in Islamic tradition as "the year of the elephant" ( 'ām al-fï), even if there is no evidence that Abraha raided M ecca, as the Arabic literature recounts. The Islamic tradition claims that M uhammad was born in that year but this does not seem to be anything else than a confluence of two events that were later deemed highly significant (Conrad 1987). Ethiopians were not there to stay, however. By 575, the Persians had conquered the whole of Yemen and expelled the Ethiopian troops.

\section{Ghassānids and Lakhmids}

Two North Arabian tribes, the Banū Ghassān and Banū Lakhm rise to important positions as allies and sort of buffer states of the Byzantine Empire and the Sasanian Empire toward the end of the third century CE (Shahîd 2002; Toral-Niehoff 2014; Genequand \& Robin 2015). In the scholarly literature, they are sometimes called Jafnids and Nașrids, respectively, according to their ruling houses. The reason of them being employed in as vassals of the two great empires is given by Hoyland (2009: 380) as follows: “Rome's struggle with a re-energised Iranian Empire led by the Sasanian dynasty (inaugurated in 224 CE) meant that it had an increased need for military manpower and allies. Peripheral people were thus incorporated in the Empire in larger numbers, and consequently they could negotiate with Rome on better terms."

The Ghassānids first appear in two Ancient South Arabian inscriptions dated to ca. 260 and $360 \mathrm{CE}$ (Robin 2015: 111-113). To these can be added a late Nabataean Aramaic inscription found in al-Qațía in the Hijāz that Robin (2015: 114; his reading and translation require modification as given here) ${ }^{8}$ dates to the third-fourth centuries on the basis of paleography. It reads: bl dkyr nšyb ḥrtt br zydmnwtw mlk 'šn, "Indeed be remembered the relative-in-law of Ḥārithat son of Zydmnwtw, King of Ghassān."

Thereafter, the Ghassānids appear in the epigraphic record and literary evidence. The Jabal Usays inscription, dated 528-9, is written by a person that the Ghassānid king had sent for some sort of military activity: "I am Ruqaym son of M u'arrif al-Awsī; the king al-Hārith [ibn Jabala] sent me to Usays as a guard [? $\mathrm{msl} h \mathrm{~h} / \mathrm{mts} \mid \underline{h h}$, the interpretation is uncertain] in the year $4 \times 100+20+3$ [of the Province $=528-9 \mathrm{CE}$ ]" (Larcher 2010, Macdonald 2010). Al-Ḥārith's son al-M undhir (phylarch of Byzantium 570-581) is remembered in an inscription from Resafa, reading, in Greek, "the fortune of al-M undhir is victorious" (Cameron 2012: 174). It is important to note that while both the Ghassānids and Lakhmids were Arabicspeaking, they usually resorted to Greek or Syriac in writing.

\footnotetext{
${ }^{8}$ I thank Nathaniel Miller for this reference.
} 
By the fourth century, Christianity had spread to the Northern parts of Arabia (al-M as'ūdī, Murūj: I, 76, 81; Hoyland 2001: 147-150) as well as some places in the South, such as Najrān. The spread of Christianity can be documented not only from the literary evidence but also from the emergence of crosses in rock graffiti, for example in Kilwa in the north-western Peninsula (Finster 2009: 72). The Ghassānids had also converted and were staunch supporters of Christianity. For instance, the Ghassānid king al-Nu'mān ibn al-M undhir (phylarch of the Byzantine Empire 581-602, not to be confused with the Lakhmid king of the same name who ruled around the same time) is characterized in the Greek and Syriac sources "a zealous Christian man" (Hoyland 2010b: 48).

At times, the Byzantines employed other tribes than Ghassānids as their allies and clients. One must mention especially the Șālihids in this connection (Shahîd 1989: 233-324). One of their kings seem to be attested in a late Nabataean inscription found recently from the Hijāz that reads: "Indeed be remembered Pahmū son of 'Ubaydū for good and may he remain safe and sound; in the year $2 \times 100+100+20+20+10$ [of the Province $=455$ CE] when they introduced 'Amrū as king" (Nehmé 2009: 49-52). This is an important and rare document that appears to refer to the Șālihid king 'Amr ibn Duj'um/Zokomos that reigned in the fifth century and that is mentioned by Greek and Arabic authors (Shahîd 1989: 252-255).

The bilingual (Parthian-M iddle Persian) Paikuli inscription dated 293 CE is the first record of the Lakhmids (Toral-Niehoff 2014: 30). There, the Lakhmid king 'Amr (r. ca. 270-300) is mentioned among the vassals of the Sasanians. For the son of 'Amr we also have epigraphic evidence: in the Namara funerary inscription of $328 \mathrm{CE}$, the Lakhmid king M ar' al-Qays ibn 'Amr is claimed to have been the "King of all Arabs" and that he subdued different Arabian tribes, raiding as far south as Najrān. However, the inscription does not mention the Persians at all; instead it is said that they (the nobles of the subdued tribes?) became phylarchs for the Romans (Bellamy 1985). Hence, it cannot be assumed that the Lakhmids were the submissive clients of the Persians for three centuries but maintained some independence. It is possible that already M ar' al-Qays ibn 'Amr had converted to Christianity, but be that as it may, it is strongly suggested in Arabic as well as some non-Arabic sources that the Lakhmids and the inhabitants of the area they ruled were Christian at least some time later (Toral-Niehoff 2009).

The Sasanians found a reliable ally in the Lakhmids, who built their capital in al-Hïra, near Ctesiphon (on al-Hīra, see most recently Toral-Niehoff 2014). According to the Arabic sources, the relationship between the Sasanian ruling family and the Lakhmids was close and often amiable. It is, for instance, said that the Sasanian king Bahrām V Gūr (r. 420-438) was brought up in the Lakhmid court of al-Ḥira (alM as'ūdī, M urūj: I, 303; Daryaee 2009: 22-23), but this might be an unreliable report. According to Isabel Toral-Niehoff (2013: 123), "such legendary material should be read as symbolic cultural legends that personalize the Iranian-Arab cultural contact." In the early sixth century, the Lakhmids played an important role in Persian military operations; this is attested also in the non-Arabic literature and is thus more strongly grounded on history (Hoyland 2007: 228-229). 
According to the Arabic sources, the strong interaction of North Arabians with the Sasanian Persia goes back to the early years of Shāpūr II's reign (309-379 CE), when North Arabians raided some provinces of the empire. Later, the king avenged and the Arabian tribes of Taghlib, 'Abd al-Qays, Tamīm, Bakr ibn Wā'il and Ḥanāẓila are said to have been forcibly removed and resettled inside the Sasanian Persia (alM as'ūdī, M urūj: I, 295; Daryaee 2009: 16-17). The presence of North Arabians in M esopotamia had of course a long history (Eph'al 1984) but their number probably increased during the Sasanian period.

The last Lakhmid king al-Nu'mān III ibn al-M undhir was killed by the Sasanians in 602 CE (Hoyland 2001: 30; Dayraee 2009: 33). The Lakhmids were replaced by another Arabian tribe, Țayyi', which ruled in al-Ḥirra for nine years. After this, al-Hīra was directly ruled by the Persians.

The decades before the Islamic conquests were characterized by the renewal of hostilities between the Byzantine and Sasanian Empires in different clashes and wars, the last war occurring in the years 603630 (on these wars, see Howard-J ohnston 1995; Greatrex \& Lieu 2002: 182-228; Dignas \& Winter 2007; Hoyland 2010b: 45-85; Fisher 2011; Sarris 2011; Cameron 2012: 191-198; M illar 2013). The inaptly named "Endless Peace" treaty of 561 between the empires came to an end when the Byzantine emperor Justin II opened hostilities in the year 572. He also planned a failed attempt at the life of the Ghassānid king alM undhir, which led to severing the ties between the Ghassānids and Byzantines. However, al-M undhir was soon once again on the Byzantine side, fighting with the general M aurice against the Persians. The fighting between the Byzantine and Sasanian sides was indecisive, however, with truces being called and then broken. The Arabian clients of Persians and Byzantines also conducted proxy war against each other (on the importance of the Arabian allies, see Hoyland 2010b: 47-48; Cameron 2012: 193).

However, in the 610s things started to change. During the reign of Khosrow II (590-628), the Persian armies advanced westward, conquering Syria, Egypt, and many cities of Asia Minor. Jerusalem was reduced in 614 and the True Cross taken, alongside the patriarch, to Ctesiphon, the Persian capital. The loss of land, goods, and prestige was a serious blow to the Byzantine Empire.

The Byzantine Empire started to recover and launch counterattacks in the 620 s, during the reign of Heraclius (r. 610-641). This did not stop the Persians from threatening Constantinople, the Byzantine capital, in 626. But soon their fortunes turned. Forming an alliance with the Turks, Heraclius attacked Persian lands decisively, which made the Persian king sue for peace in 629. The True Cross was recovered and taken back to Jerusalem in the year 630. The Sasanian Empire fell into disarray, with different factions fighting each other and kings coming to throne just to be unseated by the next (see al-Tabarī, Ta'rïkh: I, 1061-1067 for a possible list of kings). No wonder, then, that when the early Muslims started to raid the Near East in the 630s, the resistance from the Byzantines and Persians was not strong enough to stop them. 


\section{Conclusions}

Today, we understand the religious phenomena of Arabia much better than before. Especially epigraphy has taken great strides, and we are not anymore so dependent on the tendentious Arabic literary sources of the Islamic era. Arabia in general and the Hijāz in particular are regions where both polytheistic and monotheistic beliefs and practices are attested on the eve of Islam. Neither polytheism nor monotheism should be downplayed or disregarded even if it must be conceded that we do not as of yet fully understand the interaction or the power relations of the two and of nascent Islam.

M onotheism was quickly advancing in the region but traditional polytheism, with all its variety, still had its supporters. But not for long. An Arabian Prophet called M uhammad, "Highly Praised," was about to start receiving a new revelation that continued the monotheistic tradition. Islam should be seen being part of the tendency towards monotheism in late antiquity. After a long history of millennia, polytheism in the Near East came to its end with the career of the Arabian Prophet who himself had grown up as a "pagan" worshipping the local gods (Kister 1970) but who proved in the end to be their staunchest opponent.

\section{Bibliography}

Al-Jallad, Ahmad, 2014: On the Genetic Background of the Rbbl bn Hf'm Grave Inscription at Qaryat al-Faw. Bulletin of the School of Oriental and African Studies 77/3: 1-21.

Al-Jallad, Ahmad, 2015: An Outline of the Grammar of the Safaitic Inscriptions. (Studies in Semitic Languages and Linguistics 80) Leiden: Brill.

Al-Jallad, Ahmad, forthcoming: The Linguistic Landscape of pre-Islamic Arabia - Context for the Qur'ān. In: M uhammad Abdel Haleem \& M ustafa Shah (eds.): The Oxford Handbook of Qur'anic Studies. Oxford: Oxford University Press.

Athanassiadi, Polymnia \& Michael Frede, 1999: Pagan M onotheism in Late Antiquity. Oxford: Clarendon Press.

Al-Azraqī, 1858: Akhbār M akka. Ed. Ferdinand Wüstenfeld. Leipzig: F. A. Brockhaus.

Ball, Warwick, 2000: Rome in the East: The Transformation of an Empire. London \& New York: Routledge. 
Bashear, Suliman, 1989: Yemen in Early Islam: An Examination of Non-Tribal Traditions. Arabica 36: 327361.

Beaucamp, Joëlle \& Françoise Briquel-Chatonnet \& Christian J. Robin, 1999-2000: La persécution des chrétiens de Nagrān et la chronologie ḥimyarite. ARAM 11-12: 15-83.

Beaucamp, Joëlle \& Françoise Briquel-Chatonnet \& Christian J. Robin (eds.), 2010: Juifs et Chrétiens en Arabie aux Ve et Vle siècles: Regards croisés sur les sources. Paris: Association des amis du Centre d'histoire et civilization de Byzance.

Bellamy, James A., 1985: A New Reading of the Namara Inscription. Journal of the American Oriental Society 105/1: 31-48.

Bowersock, G. W., 1983: Roman Arabia. Cambridge, M A.: Harvard University Press.

Bowersock, G. W., 2013: The Throne of Adulis: Red Sea Wars on the Eve of Islam. Oxford: Oxford University Press.

Brock, Sebastian P. \& Susan A. Harvey (transl.), 1987: Holy Women of the Syrian Orient. Berkeley: University of California Press.

Bukharin, M ikhail D., 2009: Mecca on the Caravan Routes in Pre-Islamic Antiquity. In: A. Neuwirth \& N. Sinai $\&$ M. M arx (eds.), The Qur'ān in Context: Historical and Literary Investigations into the Qur'ānic Milieu, 115134. Leiden: Brill.

Bulliet, Richard W., 1975: The Camel and the Wheel. New York: Columbia University Press.

Bulliet, Richard W., 1980: Sedentarization of Nomads in the Seventh Century: The Arabs in Basra and Kufa. In: Philip C. Salzman (ed.), When Nomads Settle: Processes of Sedentarization as Adaptation and Response, 35-47. New York: Praeger Publishers.

Cameron, Averil, 2012: The Mediterranean World in Late Antiquity AD 395-700. $2^{\text {nd }}$ edition. London $\&$ New York: Routledge. 
Caner, Daniel F., 2010: History and Hagiography from the Late Antique Sinai. With contributions by Sebastian Brock, Richard M. Price and Kevin van Bladel. (Translated Texts for Historians 53) Liverpool: Liverpool University Press.

Conrad, Lawrence I., 1987: Abraha and M uhammad: Some Observations Apropos of Chronology and Literary Topoi in the Early Arabic Historical Tradition. Bulletin of the School of Oriental and African Studies 50/2: 225-240.

Crone, Patricia, 1987: M eccan Trade and the Rise of Islam. Oxford: Basil Blackwell.

Crone, Patricia, 2010: The Religion of the Qur'ānic Pagans: God and the Lesser Deities. Arabica 57: 151-200.

Crone, Patricia, 2012: The Qur'ānic M ushrikūn and the Resurrection (Part I). Bulletin of the Schoolr of Oriental and African Studies 75/3: 445-472.

CSAI = Corpus of South Arabian Inscriptions, http:// dasi. humnet.unipi.it/index.php?id $=42 \&$ prjld $=1 \&$ corld $=0 \&$ colld $=0$

Daryaee, Touraj, 2009: Sasanian Persia: The Rise and Fall of an Empire. London \& New York: I. B. Tauris.

Dignas, Beate \& Englebert Winter, 2007: Rome and Persia in Late Antiquity: Neighbours and Rivals. Cambridge: Cambridge University Press.

Donner, Fred M., 1980: The Bakr b. Wa'il Tribes and Politics in Northeastern Arabia on the Eve of Islam. Studia Islamica 51: 5-38.

Donner, Fred M., 1981: The Early Islamic Conquests. Princeton: Princeton University Press.

Donner, Fred M., 1998: Narratives of Islamic Origins: The Beginnings of Islamic Historical Writing. (Studies in Late Antiquity and Early Islam 14) Princeton: Darwin Press.

Donner, Fred M ., 2011: The Historian, the Believer, and the Qur'ān. In: Gabriel Said Reynolds (ed.), New Perspectives on the Qur'ān: The Qur'ān in Its Historical Context 2, 25-37. London \& New York: Routledge. 
Drory, Rina, 1996: The Abbasid Construction of the Jahiliyya: Cultural Authority in the Making. Studia Islamica 83: 33-49.

Eph'al, Israel, 1984: The Ancient Arabs: Nomads on the Borders of the Fertile Crescent $9^{\text {th }} 5^{\text {th }}$ Centuries B.C. Jerusalem: The Magnes Press.

Fahd, Toufic, 1968: Le Panthéon de l'Arabie centrale à la veille de l'Hégire. Paris: Paul Geuthner.

Farès-Drappeau, Saba, 1996: Wādī Iram: Un lieu du culte et de rassemblement des tribus arabe dans l'antiquité: Les premiers résultats de la mission épigraphique 1997. Aram 8: 269-283.

Finster, Barbara, 2009: Arabia in Late Antiquity: An Outline of the Cultural Situation in the Peninsula at the Time of M uhammad. In: A. Neuwirth \& N. Sinai \& M. Marx (eds.), The Qur'ān in Context: Historical and Literary Investigations into the Qur'ānic M ilieu, 61-114. Leiden: Brill.

Fisher, Greg, 2011: Between Empires: Arabs, Romans, and Sasanians in Late Antiquity. Oxford: Oxford University Press.

Fisher, Greg (ed.), 2015: Arabs and Empires before Islam. Oxford: Oxford University Press.

Gajda, Iwona, 2010: Quel M onothéisme en Arabie du Sud ancienne? In: Beaucamp \& Briquel-Chatonnet \& Robin 2010: 107-120.

Genequand, Denis \& Christian J. Robin, 2015 (eds.): Les jafnides: Des rois arabes au service de Byzance. (Orient \& M éditerranée 17) Paris: Éditions de Boccard.

Genequand, Denis, 2015: The Archaeological Evidence for the Jafnids and the Nașrids. In: Fisher 2015: 172213.

Greatrex, Geoffrey \& Samuel N. C. Lieu, 2002: The Roman Eastern Frontier and the Persian Wars: Part II AD 363-630. London \& New York: Routledge.

Gruendler, Beatrice, 1993: The Development of the Arabic Scripts. (Harvard Semitic Studies 43) Atlanta, Georgia: Scholars Press. 
Al-Hamdānī, al-Ḥasan ibn Aḥmad, 1963: Al-Iklīl I. Ed. Muḥammad ibn 'Alī al-Akwa' al-Ḥiwālī. Cairo: Maṭba'at al-Sunna al-M uḥammadiyya.

Hämeen-Anttila, Jaakko, 2013: Al-Kisrāwī and the Arabic Translations of Khwadāynāmag. Studia Orientalia 114: $65-92$

Hawting, Gerald R., 1999: The Idea of Idolatry and the Emergence of Islam: From Polemic to History. (Cambridge Studies in Islamic Civilization) Cambridge: Cambridge University Press.

Healey, J. F., 1993: The Nabataean Tomb Inscriptions of Mada'in Salih. (J ournal of Semitic Studies Supplement 1) Oxford: Oxford University Press.

Healey, J. F., 2001: The Religion of the Nabataeans: A Conspectus. Leiden: Brill.

Howard-Johnston, James, 1995: The Two Great Powers in Late Antiquity: A Comparison. In: Averil Cameron (ed.), The Byzantine and Early Islamic Near East III: States, Resources and Armies, 157-226. (Studies in Late Antiquity and Early Islam 1) Princeton: Darwin Press.

Hourani, George F., 1979: Arab Seafaring in the Indian Ocean in Ancient and Early M edieval Times. Expanded edition by John Carswell. Princeton: Princeton University Press.

Hoyland, Robert G., 2001: Arabia and the Arabs from the Bronze Age to the Coming of Islam. London \& New York: Routledge.

Hoyland, Robert G., 2007: Epigraphy and the Emergence of Arab Identity. In: P. M. Sijpensteijn et al. (eds.), From al-Andalus to Khurasan: Documents from the Medieval M uslim World, 219-242. (Islamic History and Civilization, Studies and Texts 66) Leiden.

Hoyland, Robert G., 2009: Arab Kings, Arab Tribes and the Beginnings of Arab Historical M emory in Late Roman Epigraphy. In: Hannah M. Cotton \& Robert G. Hoyland \& Jonathan J. Price \& David J. Wasserstein (eds.), From Hellenism to Islam: Cultural and Linguistic Change in the Roman Near East, 374-400. Cambridge: Cambridge University Press. 
Hoyland, Robert G., 2010a: M ount Nebo, Jabal Ramm, and the Status of Christian Palestinian Aramaic and Old Arabic in Late Roman Palestine and Arabia. In: M. C. A. M acdonald (ed.), The Development of Arabic as a Written Language, 29-46. (Supplement to the Proceedings of the Seminar for Arabian Studies 40) Oxford: Archaeopress.

Hoyland, Robert G., 2010b (ed. and transl.): Theophilus of Edessa's Chronicle and the Circulation of Historical Knowledge in Late Antiquity and Early Islam. (Translated Texts for Historians 57) Liverpool: Liverpool University Press.

Hoyland, Robert G., 2011: The Jews of the Hijaz in the Qur'ān and in Their Inscriptions. In: Gabriel Said Reynolds (ed.), New Perspectives on the Qur'ān: The Qur'ān in Its Historical Context 2, 91-116. London \& New York: Routledge.

Ḥusayn, Ṭāhā, 1926: Fī al-Shi 'r al-Jāhilī. Cairo: Dār al-Kutub.

Ibn al-Kalbī, 1995: Al-Aṣnām. Ed. Aḥmad Zakā Bāshā. Cairo: Dār al-Kutub al-M ișriyya.

Kister, M. J., 1965: M ecca and Tamīm (Aspects of Their Relations). Journal of the Economic and Social History of the Orient 8: 113-163.

Kister, M. J., 1970: 'A Bag of M eat': A Study of an Early Hadith. Bulletin of the School of Oriental and African Studies 33/2: 267-275.

Krone, Susanne, 1992: Die altarabische Gottheit al-Lāt. Frankfurt: Peter Lang.

Jamme, Albert, 1947: Le pantheon sud-arabe préislamique d'après les sources épigraphiques. Le M uséon 60: 55-147.

Lancaster, William \& Fidelity Lancaster, 2004: Concepts of Leadership in Bedouin Society. In: John Haldon \& Lawrence I. Conrad (eds.), The Byzantine and Early Islamic Near East VI: Elites Old and New in the Byzantine and Early Islamic Near East, 29-61. (Studies in Late Antiquity and Early Islam 1) Princeton: Darwin Press.

Landau-Tasseron, Ella, 1985: Asad from Jāhiliyya to Islām. Jerusalem Studies in Arabic and Islam 6: 1-28. 
Larcher, Pierre, 2010: In Search of a Standard: Dialect Variation and New Arabic Features in the Oldest Arabic Written Documents. In: M. C. A. Macdonald (ed.), The Development of Arabic as a Written Language, 103-112. (Supplement to the Proceedings of the Seminar for Arabian Studies 40) Oxford: Archaeopress.

Lecker, M ichael, 1989: The Banū Sulaym: A Contribution to the Study of Early Islam. Jerusalem: The Hebrew University.

Lecker, M ichael, 1994: Kindah on the Eve of Islam and during the 'Ridda'. Journal of the Royal Asiatic Society (Third Series) 4/3: 333-356.

Lecker, M ichael, 1995: M uslims, Jews and Pagans: Studies on Early Islamic M edina. (Islamic History and Civilization 13) Leiden: Brill.

Lecker, M ichael, 2005: Peoples, Tribes and Society in Arabian around the Time of M uhammad. Surrey: Ashgate Variorum.

M acdonald, M. C. A., 1995: Quelques réflexions sur les Saracènes, l'inscription de Rawwāfa et l'armée Romaine. In: H. Lozachmeur (ed.), Présence arabe dans le Croissant fertile avant l'Hégire. Paris: Éditions Recherche sur les Civilisations.

Macdonald, M. C. A., 2000: Reflections on the Linguistic M ap of Pre-Islamic Arabia. Arabian Archaeology and Epigraphy 11: 28-79.

M acdonald, M. C. A., 2008: Old Arabic (Epigraphic). In: K. Versteegh (ed.), Encyclopedia of Arabic Language and Linguistics, III, 464-477. Leiden: Brill.

Macdonald, M. C. A., 2009a: Arabs, Arabias, and Arabic before Late Antiquity. Topoi 16: 277-332.

M acdonald, M. C. A., 2009b: Arabians, Arabias, and the Greeks: Contacts and Perceptions. In: M. C. A. Macdonald, Literacy and Identity in Pre-Islamic Arabia, chapter 5. Surrey: Ashgate Variorum.

Macdonald, M. C. A., 2010: The Old Arabic Graffito at Jabal Usays: A New Reading of Line 1. In: M. C. A. Macdonald (ed.), The Development of Arabic as a Written Language, 141-142. (Supplement to the Proceedings of the Seminar for Arabian Studies 40) Oxford: Archaeopress. 
M acdonald, M. C. A., 2012: Goddesses, Dancing Girls or Cheerleaders? Perceptions of the Divine and the Female Form in the Rock Art of Pre-Islamic North Arabia. In: Dieux et déesses d'Arabie: Images et representations, 261-297. (Orient \& M éditerranée 7) Paris: De Boccard.

M argoliouth, D. S., 1925: The Origins of Arabic Poetry. Journal of Royal Asiatic Society (1925): 417-449.

al-M as'ūdī, 1979: M urūj al-Dhahab wa-M a ādin al-Jawhar. Ed. Charles Pellat. Seven volumes. Beirut: Publications de l'universite libanaise.

Millar, Fergus, 2013: Religion, Language and Community in the Roman Near East: Constantine to Muhammad. Oxford: Oxford University Press.

M unt, Harry, 2015: "No Two Religions": Non-M uslims in the Early Islamic Hijāz. Bulletin of the Schoolr of Oriental and African Studies 78/2: 249-269.

Nebes, Norbert \& Peter Stein, 2008: Ancient South Arabian. In: Roger D. Woodard (ed.), The Ancient Languages of Syria-Palestine and Arabia, 145-178. Cambridge: Cambridge University Press.

Nebes, Norbert, 2009: The Martyrs of Najrān and the End of the Himyar: On the Political History of South Arabia in the Early Sixth Century. In: In: A. Neuwirth \& N. Sinai \& M. M arx (eds.), The Qur'ān in Context: Historical and Literary Investigations into the Qur'ānic M ilieu, 27-59. Leiden: Brill.

Nehmé, Laïla, 1998: Une inscription nabatéenne de Bosra (Syrie). In: C.-B. Amphoux \& A. Frey \& U. Schattner-Rieser (eds.), Études sémitiques et samaritaines offertes à Jean Margain, 62-73. Lausanne: Éditions du zèbre.

Nehmé, Laïla, 2005: Towards an Understanding of the Urban Space of Madā'in Șāliḥ, Ancient Ḥegrā, Through Epigraphic Evidence. Proceedings of the Seminar for Arabian Studies 35: 155-175.

Nehmé, Laïla, 2009: Quelques éléments de réflexion sur Hégra et sa région à partir du lle siècle après J.-C. In: C. Robin \& J. Schiettecatte (eds.), L'Arabie à la veille de l'Islam: Un bilan clinique, 37-58. Paris: Editions De Boccard. 
Nehmé, Laïla, 2010: A Glimpse of the Development of the Nabataean Script into Arabic Based on Old and New Epigraphic Material. In: M. C. A. Macdonald (ed.), The Development of Arabic as a Written Language, 47-88. (Supplement to the Proceedings of the Seminar for Arabian Studies 40) Oxford: Archaeopress.

Nehmé, Laïla, 2013: Epigraphy on the edges of the Roman Empire: A study of the Nabataean inscriptions and related material from the Darb al-Bakrah, Saudi Arabia, 1st-5th century AD. Volume 1: Text \& illustrations. Unpublished habilitation thesis. École pratique des hautes études.

Newby, G. D., 1988: A History of the Jews of Arabia: From Ancient Times to Their Eclipse under Islam. Columbia: University of South Carolina Press.

Peters, F. E. (ed.), 1999: The Arabs and Arabia on the Eve of Islam. (The Formation of the Classical Islamic World 3) Aldershot: Ashgate Variorum.

Piacenza Pilgrim, Itinerarium =Caner 2010: 252-262.

Potts, Daniel T., 1990-1: The Arabian Gulf in Antiquity. Two vols. Oxford: Clarendon Press.

Rabin, Chaim, 1951: Ancient West-Arabian: A Study of the Dialects of the Western Highlands of Arabia in the Sixth and Seventh Centuries A.D. London: Taylor's Foreign Press.

Retsö, Jan, 2003: The Arabs in Antiquity: Their History from the Assyrians to the Umayyads. London \& New York: Routledge.

Rihan, M ohammad, 2014: The Politics and Culture of an Umayyad Tribe: Conflict and Factionalism in the Early Islamic Period. London \& New York: I. B. Tauris.

Rippin, Andrew, 2012: Muslims: Their Religious Beliefs and Practices. $4^{\text {th }}$ edition. London $\&$ New York: Routledge.

Robin, Christian J., 2001: Les inscriptions de l'Arabie antique et les études arabes. Arabica 48: 509-577. Robin, Christian J., 2003: Le judaïsme de Ḥimyar. Arabia 1: 97-172.

Robin, Christian J., 2015: Ghassān en Arabie. In: Genequand \& Robin 2015, 79-120. 
Robinson, Chase F., 2010: Introduction. In: Chase F. Robinson (ed.), The New Cambridge History of Islam Volume 1: The Formation of the Islamic World, Sixth to Eleventh Centuries, 1-15. Cambridge: Cambridge University Press.

Rose, Jenny, 2011: Zoroastrianism: An Introduction. London \& New York: I. B. Tauris.

Ryckmans, J. \& W. W. Müller \& Y. M. Abdallah, 1994: Textes du Yémen antique inscrits sur bois. Louvain-laNeuve: Université Catholique de Louvain, Institut Orientaliste.

Sarris, Peter, 2011: Empires of Faith: The Fall of Rome to the Rise of Islam, 500-700. Oxford: Oxford University Press.

Savignac, R., 1933: Le sanctuaire d'Allat à Iram [II]. La Revue Biblique 42: 405-422.

Shahîd, Irfan, 1984a: Byzantium and the Arabs in the Fourth Century. Washington, D.C.: Dumbarton Oaks.

Shahîd, Irfan, 1984b: Rome and the Arabs: A Prolegomenon to the Study of Byzantium and the Arabs. Washington, D.C.: Dumbarton Oaks.

Shahîd, Irfan, 1989: Byzantium and the Arabs in the Fifth Century. Washington, D.C.: Dumbarton Oaks.

Shahîd, Irfan, 2000: Thamūd. In: Encyclopaedia of Islam $2^{\text {nd }}$ ed., X, 436. Leiden: Brill.

Shahîd, Irfan, 2002: Byzantium and the Arabs in the Sixth Century, Volume II, Part 1. Washington, D.C.: Dumbarton Oaks.

Stetkevych, Jaroslav, 1996: M uhammad and the Golden Bough: Reconstructing Arabian Myth. Bloomington \& Indianapolis: Indiana University Press.

Stetkevych, Suzanne P., 1993: The M ute Immortals Speak: Pre-Islamic Poetry and the Poetics of Ritual. Ithaca, New York: Cornell University.

Al-Ṭabarī, M uhammad ibn Jarīr, 1879-1901: Ta'rikh al-Rusul wa-I-Mulūk. Ed. M. J. de Goeje \&al. as Annales. Three volumes in 15. Brill: Leiden. Transl. The History of al-Ṭabarī. 40 volumes. Albany: State University of New York Press. 
Toral-Niehoff, Isabel, 2009: The 'Ibād Of Al-Ḥira: An Arab Christian Community in Late Antique Iraq. In: A. Neuwirth \& N. Sinai \& M. M arx (eds.), The Qur'ān in Context: Historical and Literary Investigations into the Qur'ānic Milieu, 323-348. Leiden: Brill.

Toral-Niehoff, Isabel, 2013: Late Antique Iran and the Arabs: The Case of al-Hira. Journal of Persianate Studies 6: 115-126.

Toral-Niehoff, Isabel, 2014: Al-Hīra: Eine arabischen Kulturmetropole im spätantiken Kontext. Leiden: Brill.

Triningham, J. S., 1979: Christianity among the Arabs in Pre-Islamic Times. London: Longman.

Watt, William M., 1971: Belief in a "High God" in Pre-Islamic M ecca. Journal of Semitic Studies 16: 35-40.

Yãqūt al-Rūmī al-Ḥamawī, 1977: M u jam al-Buldān. Five volumes. Beirut: Dār șādir.

Young, Gary K., 2001: Rome's Eastern Trade: International Commerce and Imperial Policy 31 BC-AD 305. London \& New York: Routledge.

Zwettler, M ichael, 1978: The Oral Tradition of Classical Arabic Poetry: Its Character and Implications. Columbus: Ohio State University Press. 